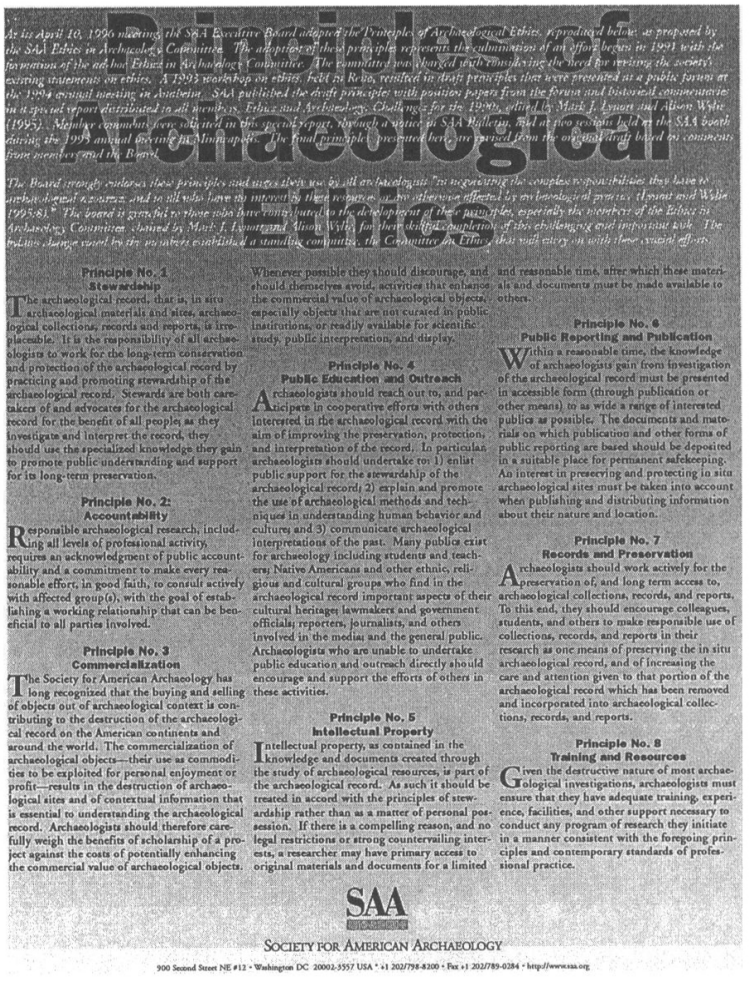

The Principles of Archaeological Ethics poster. This attractive, $221 \frac{1}{2}$ " x 171/2", laminated, blue and gold poster of the Principles of Archaeological Ethics adopted by the SAA. Culminating five years of discussion and comment, these principles reflect the changing face of archaeology. Having these Eight Principles in poster form provides an opportunity for you to bring them to everyone's attention. Be sure to get one for the Department or the business office, and display it prominently in your Lab and in your classroom. \$4.95 plus \$5.00 Shipping \& Handling. Check, Visa, Mastercard accepted. Send to: Ethics Poster, SAA Office, 900 Second Street Suite 12, Washington DC 20002. Questions? 202/789-8200 rick_peterson@saa.org 


\section{Statement of Ownership, Management, and Clrculation}

\begin{tabular}{|c|c|c|c|c|c|c|c|c|c|}
\hline \multirow{2}{*}{$\begin{array}{l}\text { 1. Publleation THle } \\
\text { AMERICAN ANTIQUITY }\end{array}$} & \multicolumn{8}{|c|}{ 2. Publicalion Number } & \multirow{2}{*}{$\begin{array}{l}\text { 3. Fing Date } \\
\text { Sept } 24,1999\end{array}$} \\
\hline & 0 & 0 & 0 & 2 & -7 & 3 & 1 & 6 & \\
\hline 4. Issue Frequency & \multicolumn{8}{|c|}{ 5. Number of lasues Published Annually } & 6. Annual Subsertption Price \\
\hline Quarterly (Jan, April, July, Oct) & \multicolumn{8}{|c|}{4} & $\$ 175.00$ \\
\hline \multicolumn{9}{|c|}{ 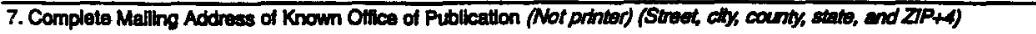 } & Contact Person \\
\hline \multicolumn{9}{|c|}{$\begin{array}{l}\text { SOCIETY FOR AMERICAN ARCHAEOLOGY } \\
900 \text { Second St NE, Suite } 12 \\
\text { Washington, DC } 20002\end{array}$} & $\begin{array}{l}\text { Elizabeth Foxwell } \\
\text { Tolophone } \\
202 / 789-8200\end{array}$ \\
\hline
\end{tabular}

8. Complate Maling Address of Headquarters or General Business Otilce of Publisher (Not printer)

SAME AS ABOVE

9. Full Names and Complete Maling Addresses of Publlsher, Edttor, and Managing Edthor (Do not leave blank)

Publisher (Name and complote malling nodrose)

SOCIETY FOR AMERICAN ARCHAEOLOGY

900 Second St NE, Suite 12

Washington, DC 20002

Edilor fNamo and compleis malling actrases)

LYINNE GOLDSTEIN, Dept of Anthropoiogy

Michigan State University

East Lansing, MI 48824-.

Managing Editor (Nemo and complobs malling ededress)

ELIZABETH FOXWELL, Society for American Archaeology

900 Second St NE, Suite 12

Washington, DC 20002

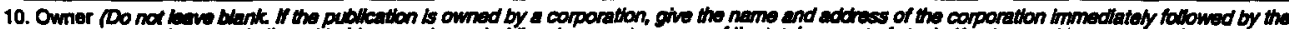

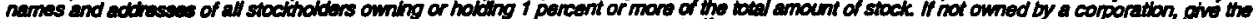

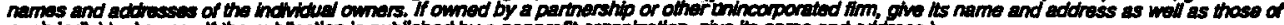

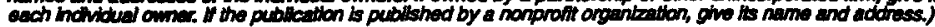

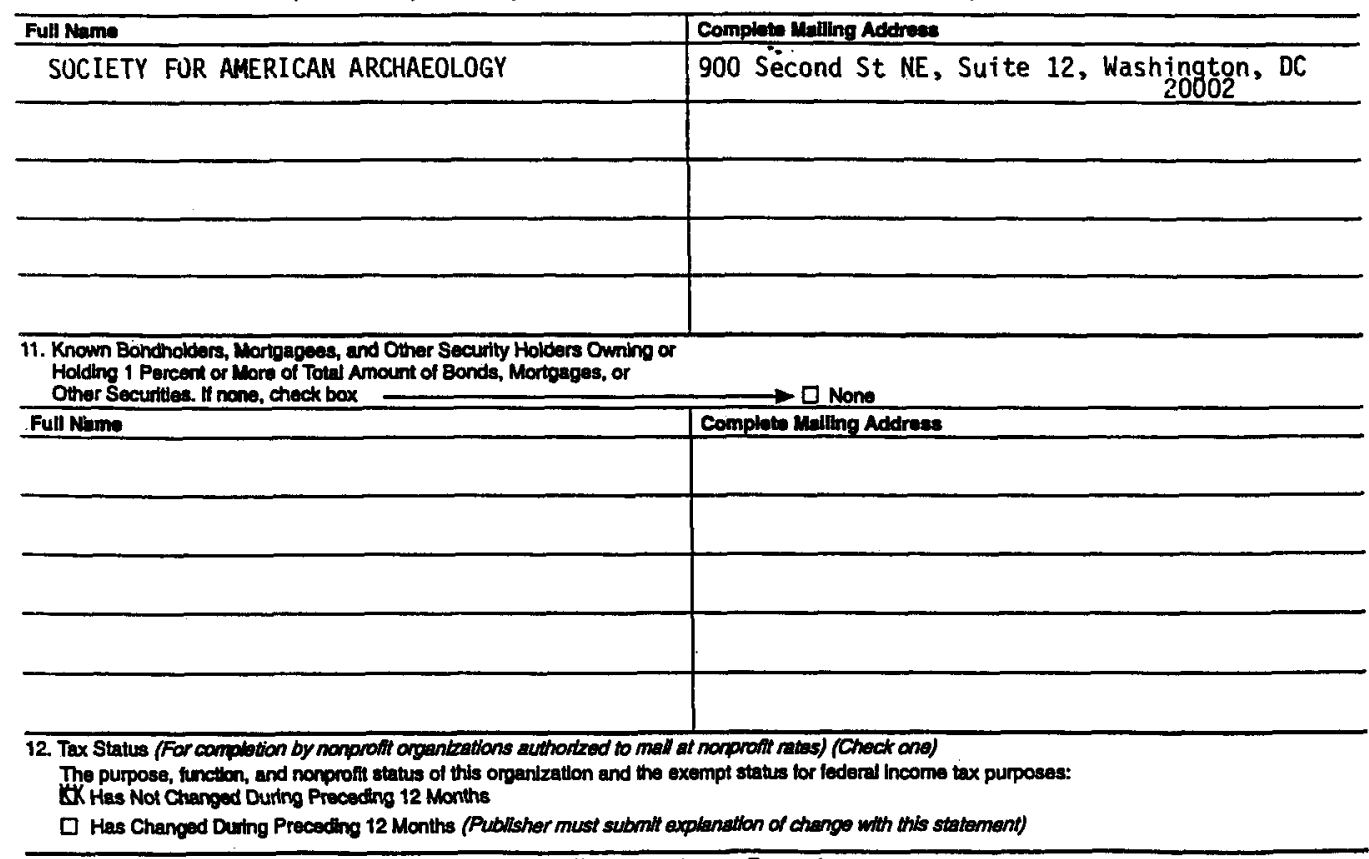

PS Form 3526, September 1998

(See Instructions on Reverse) 


\begin{tabular}{|c|c|c|c|c|}
\hline \multicolumn{3}{|c|}{$\begin{array}{l}\text { 13. Publication Tite } \\
\text { AMERICAN ANTIQUITY }\end{array}$} & \multicolumn{2}{|c|}{$\begin{array}{l}\text { 14. Liseve Data for Cratatation Data Bolow } \\
\text { JULY } 1999\end{array}$} \\
\hline 15. & & Extent and Nature of Cireulation & $\begin{array}{l}\text { Avernge No. Copies Eech laves } \\
\text { During Proceding } 12 \text { Months }\end{array}$ & $\begin{array}{l}\text { No. Copies of Single lanue } \\
\text { Published Nonrest to Filling Date }\end{array}$ \\
\hline \multicolumn{3}{|c|}{ a. Total Number of Coples (Not press run) } & 6,662 & 6,500 \\
\hline \multirow{4}{*}{$\begin{array}{l}\text { b. Paid and/or } \\
\text { Requested } \\
\text { Clrculation }\end{array}$} & (1) & 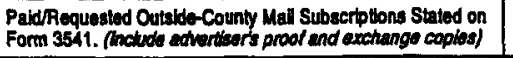 & 6,401 & 6,321 \\
\hline & (2) & $\begin{array}{l}\text { Pald In-County Subactiptiona (metude odvertiser's proot } \\
\text { and exchange copies) }\end{array}$ & & \\
\hline & (3) & $\begin{array}{l}\text { Sales Through Deaiers and Carriars, Street Vendors, } \\
\text { Counter Sales, and Othar Non-USPS Pald Diatibution }\end{array}$ & & \\
\hline & (4) & Other Clasages Meiled Through the USPS & & \\
\hline \multicolumn{3}{|c|}{$\begin{array}{l}\text { c. Total Pald and/or Requested Clrculation (SCm of 15b. (1), (2), (3), and } \\
\text { (4)] }\end{array}$} & 6,401 & 6,321 \\
\hline \multirow{3}{*}{$\begin{array}{l}\text { Free } \\
\text { Distribution } \\
\text { by Mall } \\
\text { (Samples. } \\
\text { compliment } \\
\text { ay, end } \\
\text { other froe) }\end{array}$} & (1) & Oulside-Counly as Stated on Fom 3541 & \multirow[t]{3}{*}{24} & \multirow[t]{3}{*}{24} \\
\hline & (2) & In-County as Stated on Form 3541 & & \\
\hline & (3) & Other Classea Malled Through the USPS & & \\
\hline \multicolumn{3}{|c|}{ 6. Free Distribution Outside the Mall (Carrors or other means) } & & . \\
\hline \multicolumn{3}{|c|}{ f. Total Free Distribution (Sum of 15d. and 15a.) } & 24 & 24 \\
\hline \multicolumn{3}{|c|}{ 9. Total Distribution (Sum of 15a and 151) } & 6,425 & 6,345 \\
\hline \multicolumn{3}{|c|}{ Coples not Distributed } & 260 & 155 \\
\hline \multicolumn{3}{|c|}{ Total (Sum of 15g. and h) } & 6,685 & 6,500 \\
\hline \multicolumn{3}{|c|}{ 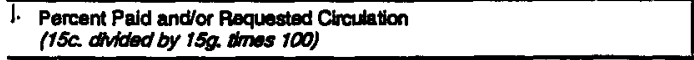 } & $99.62 \%$ & $99.62 \%$ \\
\hline \multicolumn{4}{|c|}{$\begin{array}{l}\text { 16. Publication of Statemant of Ownership } \\
\text { XI Publication required. Wil be printed in the January } 2000\end{array}$} & D Publication not requirad. \\
\hline \multicolumn{4}{|c|}{ 17. Slgnature and Tite of Edthor, Pubilshar Busgness Mengger, or Owner } & Dept 24, 1999 \\
\hline
\end{tabular}

I certlly that all iniormation furnishad on this form is true and complete. I understand that anyone who fumishes faise or misleading Information on thls form or who omits matertal or tritormation requested on the form may be subject to eriminal sanctions (inalualing fines and imprisonme ni) and/or civil sanctions (including ctvil penalties).

\section{Instructions to Publishers}

1. Complete and flie one copy of this form with your postmaster annually on or before October 1. Keep a copy of the completed form for your records.

2. In cases where the stockholder or security holder is a trustee, Include in items 10 and 11 the name of the person or corporation for whom the trustee is acthn. Asso include the names and addresses of indivituals who are stockholders who own or hold 1 percent or more of the total amount of bends, mortgages, or other securities of the publishing corporation. In item 11, if none, check the box. Use blank sheets if more space is required.

3. Be sure to fumish all circulation information called for in item 15 . Free circulation must be shown in ltems $15 d, e$, and $f$.

4. Item 15h., Coples not Distributed, must include (1) newsstand copies originally stated on Fom 3541 , and returned to the publisher, (2) estimated retums from news agents, and (3), copies for office use, leftovers, spolled, and all other coples not distributed.

5. If the publication had Periodicals authorization as a general or requester publication, this Statement of Ownership, Management, and Circutation must be published; it must be printed in any issue in October or, if the publication is not published during October, the first isese printed after October.

6. In hem 16. Indlcate the date of the issue in which this Statement of Ownership will be published.

7. Item 17 must be signed.

Fallure to fle or publish a statement of ownershlp may load to suspenston of Perlodocals authortzation. 


\section{NOTICE TO AUTHORS}

American Antiquity publishes original papers on the archaeology of the New World and on archaeological method, theory, and practice worldwide. Authors of papers on Latin American topics are encouraged to submit their work to Latin American Antiquity. Papers on Latin American archaeology addressing broad methodological, theoretical, or comparative issues may be accepted by either journal after consultation with the editors. Authors submit manuscripts to the editor for consideration as ARTICLES, REPORTS, COMMENTS, or FORUM essays. REVIEWS and BOOK NOTES are solicited by the respective associate editor. OBITUARIES should be submitted to the editor, SAA Bulletin, for publication (see SAA Bulletin March/April 1996, p. 7, for further details).

Authors should submit an original and four copies of their manuscripts, including all figures, tables, references, and notes. Detailed information on policy, style, and technical matters of manuscript preparation is given in the "Editorial Policy, Information for Authors, and Style Guide for American Antiquity and Latin American Antiquity," which appeared in the October 1992 issue (57:749-770) and can be read on the World Wide Web at http://www.saa.org/Publications/StyleGuide/styframe.html.

The editor reserves the right to evaluate manuscripts (with or without peer review) for appropriate subject matter, quality, length, and compliance with the style guide. Manuscripts may be returned to authors if they fail to meet expectations or conform to these guidelines. Manuscripts are evaluated by the editor in consultation with peer referees, as appropriate. The editor has the final responsibility for all decisions regarding manuscripts. The review process generally takes a minimum of two to four months. Authors will be notified as soon as a decision is reached to accept (outright or with revisions) or reject a manuscript.

To ensure the prompt receipt and handling of manuscripts, please send them to the editor-designate: Timothy A. Kohler, Department of Anthropology, Washington State University, Pullman, WA 99164-4910. Inquiries regarding the style guide and the production of the journal should be directed to: Elizabeth Foxwell, Society for American Archaeology, 900 Second Street, N.E., Suite 12, Washington, DC 20002-3557. 


\section{FORUM}

5 Gazing Upon the Invisible: Women and Children at the Old Baton Rouge Penitentiary

Connie H. Nobles

\section{ARTICLES}

15 Social Formations, Modo de Vida, and Conflict in Archaeology

Bradley E. Ensor

\section{REPORTS}

43 Paleoindian Colonization of the Americas: Implications from an Examination of Physiography, Demography, and Artifact Distribution

David G. Anderson and J. Christopher Gillam

67 Settlement and Sea Levels on the Central Coast of British Columbia: Evidence from Shell Midden Cores

Aubrey Cannon

79 Figurines, Flint Clay Sourcing, the Ozark Highlands, and Cahokian Acquisition

Thomas E. Emerson and Randall E. Hughes

103 Inferences about Prehistorical Ceramics and People in Southeast Missouri: Results of Ceramic Compositional Analysis

Mark J. Lynott, Hector Neff, James E. Price, James W. Cogswell, and Michael D. Glascock

127 Sex, Gender, and Status: Human Images from the Classic Mimbres

Marit K. Munson

145 Cannibalism, Warfare, and Drought in the Mesa Verde Region during the Twelfth Century A.D. Brian R. Billman, Patricia M. Lambert, and Banks L. Leonard

179 Critique of the Claim of Cannibalism at Cowboy Wash Kurt E. Dongoske, Debra L. Martin, and T.J. Ferguson

\section{COMMENTS}

191 The Buhl Burial: A Comment on Green et al. Walter A. Neves and Max Blum

\section{REVIEWS AND BOOK NOTES}

On the cover: Examples of White Mountain Redware bowls of the American Southwest. The styles are Fourmile (center), Holbrook (bottom right), Puerco (left), and Wingate (top right). Drawings by Brigid Sullivan.

The paper used in this publication meets the requirements of ANSI/NISO Z39.48-1992 (Permanence of Paper). 